\title{
Biomimetic Studies on Anti-thyroid Drugs and Thyroid Hormone Synthesis
}

Gouriprasanna Roy, Munirathinam Nethaji and G. Mugesh*

\section{Supporting Information}

\section{Experimental Section}

General Procedure: All reactions were carried out under nitrogen or argon using standard vacuum-line techniques. Solvents were purified by standard procedures and were freshly distilled prior to use. Melting points were recorded in capillary tubes and are uncorrected. ${ }^{1} \mathrm{H},{ }^{13} \mathrm{C}$ and ${ }^{77} \mathrm{Se}$ NMR spectra were obtained on a Bruker $400 \mathrm{MHz}$ NMR Spectrometer. Chemical shifts are cited with respect to $\mathrm{SiMe}_{4}$ as internal $\left({ }^{1} \mathrm{H}\right.$ and $\left.{ }^{13} \mathrm{C}\right)$ and $\mathrm{Me}_{2} \mathrm{Se}\left({ }^{77} \mathrm{Se}\right)$ as external standard.

Synthesis of the selenium analogue of methimazole (5):

This compound was synthesized by following the procedure reported for the corresponding selenone (L. J. Guziec, F. S. Guiziec, Jr. J. Org. Chem. 1994, 59, 4691).

MSeI $_{\text {ox }}$ : To a cooled $\left(-78^{\circ} \mathrm{C}\right)$ solution of 1-methylimidazole $(0.48 \mathrm{ml}, 6.09 \mathrm{mmol})$ in freshly distilled THF (50 ml) was added via syringe n-butyllithium $(3.8 \mathrm{ml}, 1.6 \mathrm{M}$ in hexanes $)$ The mixture was stirred with cooling for $35 \mathrm{~min}$ and then allowed to come to r.t. at which time elemental selenium $(0.721 \mathrm{~g}, 9.12 \mathrm{mmol})$ was added. The resulting mixture was stirred at r.t. overnight under nitrogen. After cooling, the mixture was quenched with water and neutralized with $1 \mathrm{~N} \mathrm{HCl}$. The aqueous mixture was extracted with $\mathrm{CHCl}_{3}$ and the organic layer washed with brine and dried over $\mathrm{Na}_{2} \mathrm{SO}_{4}$. Removal of solvent afforded an orange solid. The product was recrystallized from $\mathrm{CHCl}_{3}$ to give orange crystals. Yield $0.5 \mathrm{~g}(50 \%)$; m.p. $142-144{ }^{\circ} \mathrm{C} ;{ }^{1} \mathrm{H} \mathrm{NMR}\left(\mathrm{CDCl}_{3}\right) \delta: 3.52$ (s, 3H), 7.00 $(\mathrm{d}, 1 \mathrm{H}), 7.09(\mathrm{~d}, 1 \mathrm{H}) ;{ }^{13} \mathrm{C} \mathrm{NMR}\left(\mathrm{CDCl}_{3}\right) \delta: 35.25,124.70,131.32,133.06 ;{ }^{77} \mathrm{Se} \mathrm{NMR}\left(\mathrm{CDCl}_{3}\right) \quad \delta$ : 397. 
Synthesis of 7: To a solution of $0.816 \mathrm{~g}(3 \mathrm{mmol})$ of 2,6-bis(4,4-dimethyl-2-oxazoline-2yl)benzene in $20 \mathrm{ml}$ of dry benzene were added $0.89 \mathrm{ml}(9 \mathrm{mmol})$ of TMEDA and $9.0 \mathrm{mmol}$ of LDA. The mixture was stirred for $4 \mathrm{~h}$ and the resulting precipitate was dissolved in dry THF (30 $\mathrm{ml})$. The solution was cooled to $-15^{\circ} \mathrm{C}$, and then elemental selenium $(0.236 \mathrm{~g}, 3 \mathrm{mmol})$ was added. The stirring was continued for $12 \mathrm{~h}$ at r.t., and then the mixture was poured into a beaker containing saturated solution of $\mathrm{NaHCO}_{3}$. Oxygen was bubbled for $15 \mathrm{~min}$ and the solution was extracted with ether. The organic phase was dried over anhydrous sodium sulfate, and the solvent was removed in vacuo to afford dark oil. The unusually cleaved product 7 was separated by column chromatography as a stable compound on silica gel with PE/ethyl acetate (1:1) as eluent. The product was recrystallized from diethylether to give yellow crystals. Yield 0.44g (40\%); m.p. 164$166{ }^{\circ} \mathrm{C} ;{ }^{1} \mathrm{H}$ NMR $\left(\mathrm{CDCl}_{3}\right) \delta: 1.46(\mathrm{~s}, 6 \mathrm{H}), 1.63(\mathrm{~s}, 6 \mathrm{H}), 3.86(\mathrm{~d}, 2 \mathrm{H}), 4.33(\mathrm{~s}, 2 \mathrm{H}), 6.0(\mathrm{t}, 1 \mathrm{H}), 7.52$ $(\mathrm{t}, 1 \mathrm{H}), 7.91(\mathrm{~d}, 1 \mathrm{H}), 8.11(\mathrm{~d}, 1 \mathrm{H}) ;{ }^{13} \mathrm{C} \mathrm{NMR}\left(\mathrm{CDCl}_{3}\right) \delta: 167.82,162.69,141.87,131.33,130.48$, $129.10,126.30,121.13,81.66,77.26,71.28,67.26,62.69,28.77,25.99,25.93 ;{ }^{77} \mathrm{Se} \mathrm{NMR}\left(\mathrm{CDCl}_{3}\right.$, $\left.\mathrm{Me}_{2} \mathrm{Se}\right) \delta: 822$.

GPx assay:: The GPx activity was followed spectrophotometrically at $340 \mathrm{~nm}$ as described in Roveri et al. [A. Roveri, M. Maiorino, F. Ursini, Methods Enzymol. 1994, 233: 202-212] with minor modifications. The test mixture contained GSH (1 mM), EDTA (1 mM), glutathione disulfide reductase $(0.6 \mathrm{unit} / \mathrm{ml})$, and NADPH $(0.2 \mathrm{mM})$ in $0.1 \mathrm{M}$ potassium phosphate buffer, $\mathrm{pH}$ 7.3. GPx samples were added to the test mixture at room temperature and the reaction was started by the addition of $\mathrm{H}_{2} \mathrm{O}_{2}(1 \mathrm{mM})$. The initial reduction rates were calculated from the rate of NADPH oxidation at $340 \mathrm{~nm}$. Each initial rate was measured at least 3 times and calculated from the first $5-10 \%$ of the reaction by using $6.22 \mathrm{mM}^{-1} \mathrm{~cm}^{-1}$ as the extinction coefficient for NADPH. For the peroxidase activity, the rates were corrected for the background reaction between $\mathrm{H}_{2} \mathrm{O}_{2}$ and GSH.

LPO Assay: The inhibition experiments were carried out with LPO, which has been shown to have properties similar to that of TPO, which is not easy to isolate and purify without destroying its 
activity. The spectral measurements were carried out in a Perkin-Elmer spectrophotometer. The LPO enzyme activity was determined by following UV absorption increase at $411 \mathrm{~nm}$ due to the oxidation of ABTS. Enzyme activity after the addition of various inhibitors was expressed as the percentage of that observed in the absence of inhibitors.

\section{Plots for the inhibition of LPO-catalyzed ABTS oxidation by ebselen and compound 7.}

Figure 1. The incubation mixture contained $19.4 \mathrm{nM}$ LPO, $1.4 \mathrm{mM} \mathrm{ABTS,} 287 \mathrm{nM} \mathrm{H}_{2} \mathrm{O}_{2}$ and various concentrations of inhibitors in $0.067 \mathrm{M}$ potassium phosphate buffer, $\mathrm{pH} 7$; the reaction was initiated with $\mathrm{H}_{2} \mathrm{O}_{2}$.
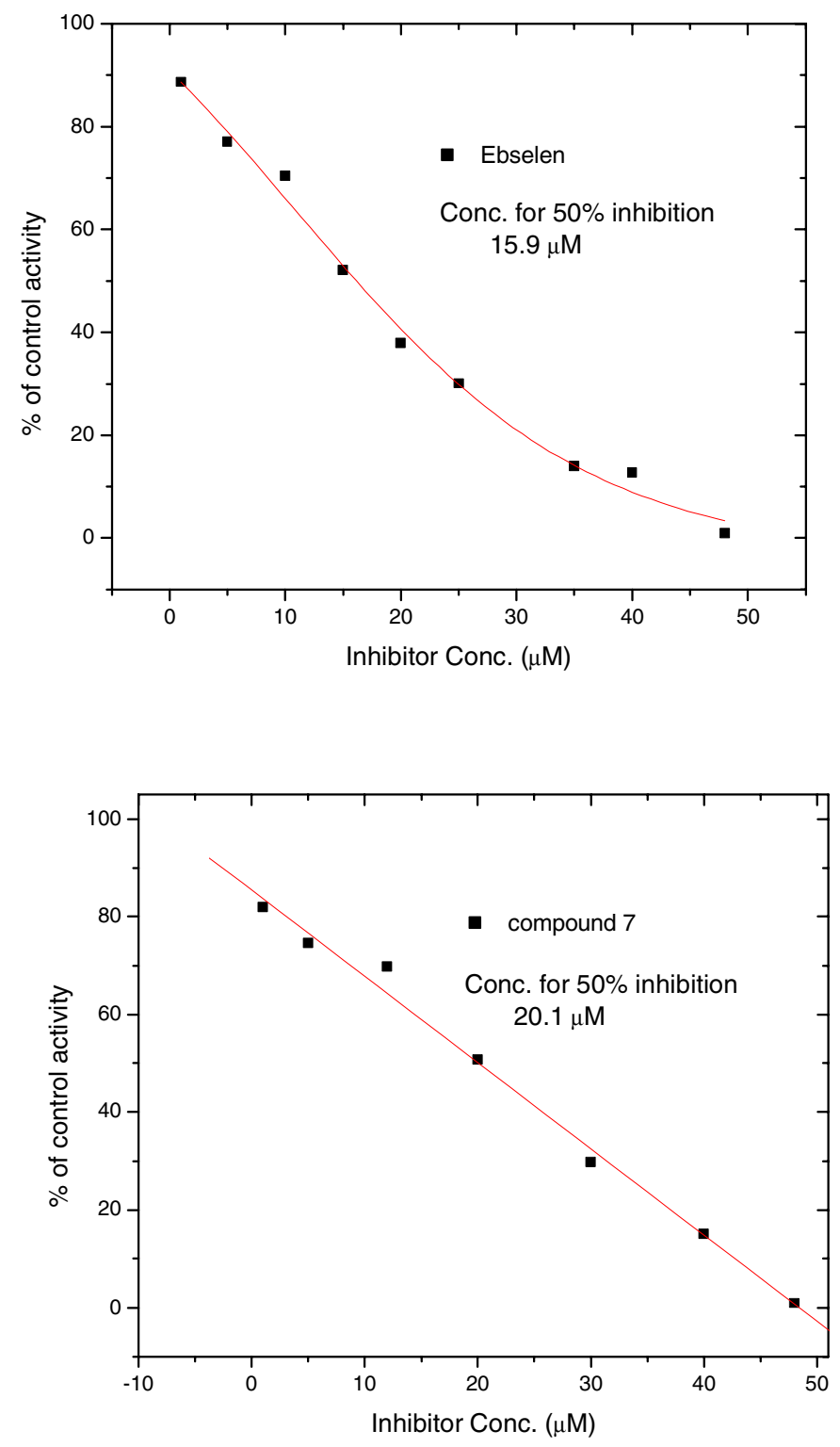
Inactivation of LPO by different inhibitors: The LPO was first treated with $\mathrm{H}_{2} \mathrm{O}_{2}$ to produce an oxidized form of LPO. Inhibitor was added after $30 \mathrm{sec}$., and after $1 \mathrm{~min}$ of contact between inhibitor and oxidized LPO, ABTS was then added and the absorbance was measured at $411 \mathrm{nM}$.

Figure 2. The incubation mixture contained $19.4 \mathrm{nM} \mathrm{LPO,} 115 \mathrm{nM} \mathrm{H}_{2} \mathrm{O}_{2}$, various concentrations of MMI and $1.4 \mathrm{mM}$ ABTS, in $0.067 \mathrm{M}$ potassium phosphate buffer, $\mathrm{pH} 7$.

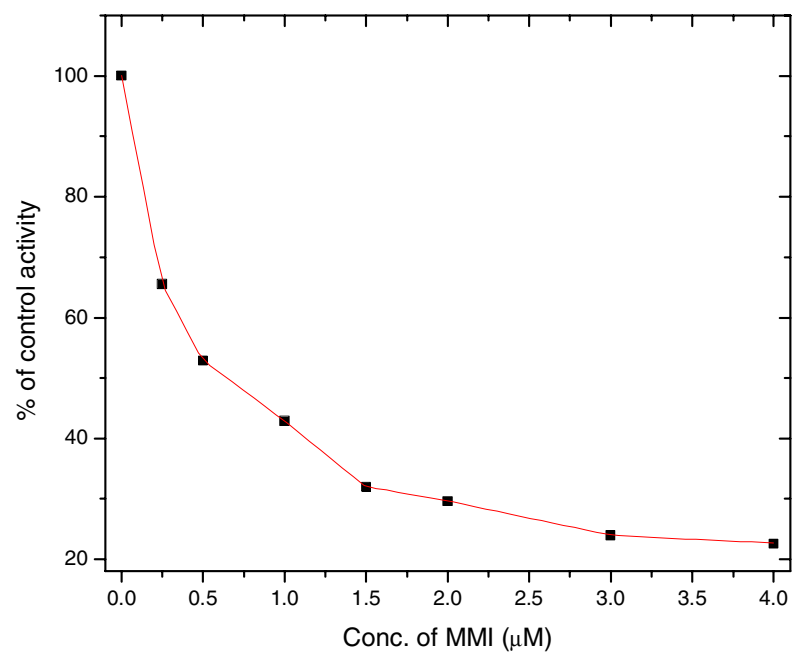

Figure 3. The incubation mixture contained $19.4 \mathrm{nM} \mathrm{LPO}, 115 \mathrm{nM} \mathrm{H}_{2} \mathrm{O}_{2}$, various concentrations of $\mathrm{MSeI}_{\mathrm{ox}}$ and $1.4 \mathrm{mM}$ ABTS, in $0.067 \mathrm{M}$ potassium phosphate buffer, $\mathrm{pH} 7$.

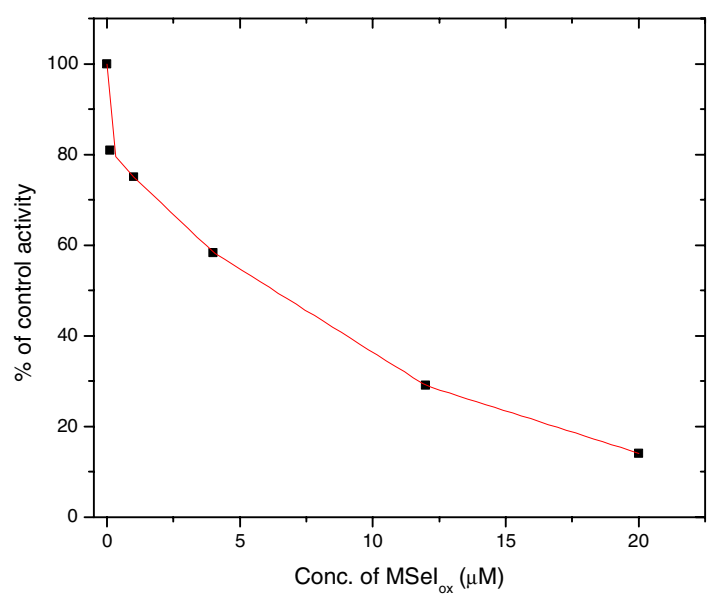


Figure 4. The incubation mixture contained $19.4 \mathrm{nM} \mathrm{LPO}, 115 \mathrm{nM} \mathrm{H}_{2} \mathrm{O}_{2}$, various concentrations of ebselen and $1.4 \mathrm{mM}$ ABTS, in $0.067 \mathrm{M}$ potassium phosphate buffer, $\mathrm{pH} 7$.

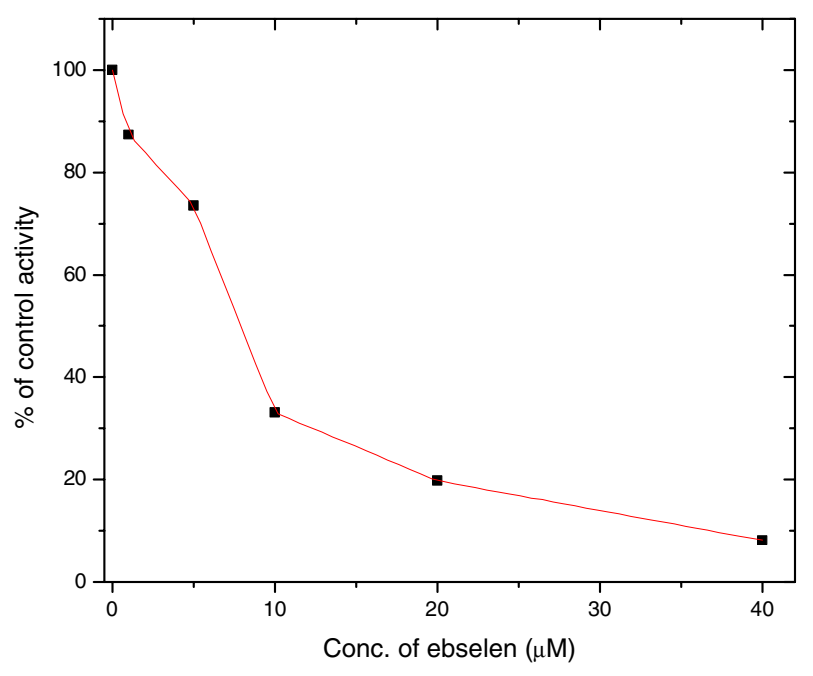

Figure 5. The incubation mixture contained $19.4 \mathrm{nM} \mathrm{LPO}, 115 \mathrm{nM} \mathrm{H}_{2} \mathrm{O}_{2}$, various concentrations of compound 7 and $1.4 \mathrm{mM}$ ABTS, in $0.067 \mathrm{M}$ potassium phosphate buffer, $\mathrm{pH} 7$.

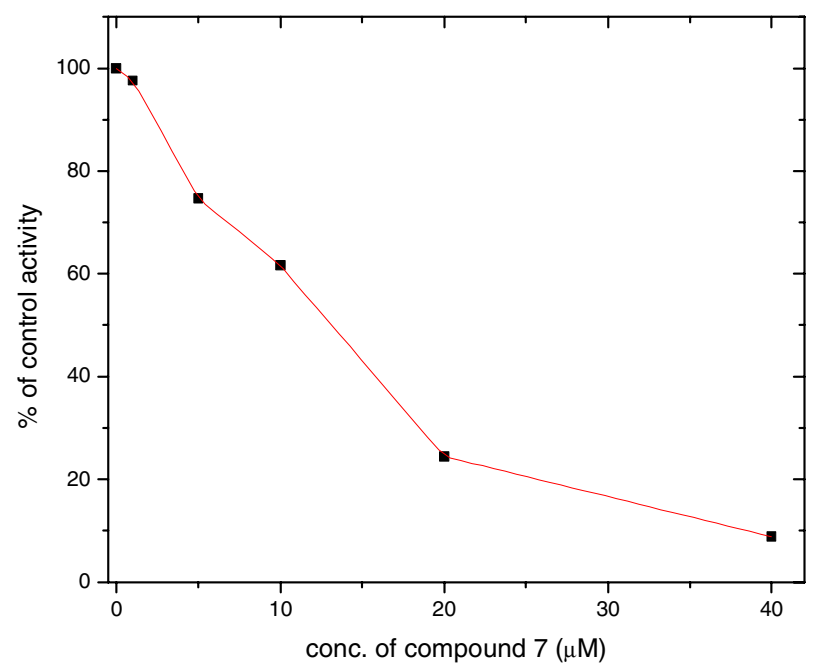


Figure 6. ${ }^{77} \mathrm{Se}$ NMR spectrum of $\mathrm{MSeI}_{\mathrm{ox}}(\mathbf{5})$ in $\mathrm{CDCl}_{3}$.

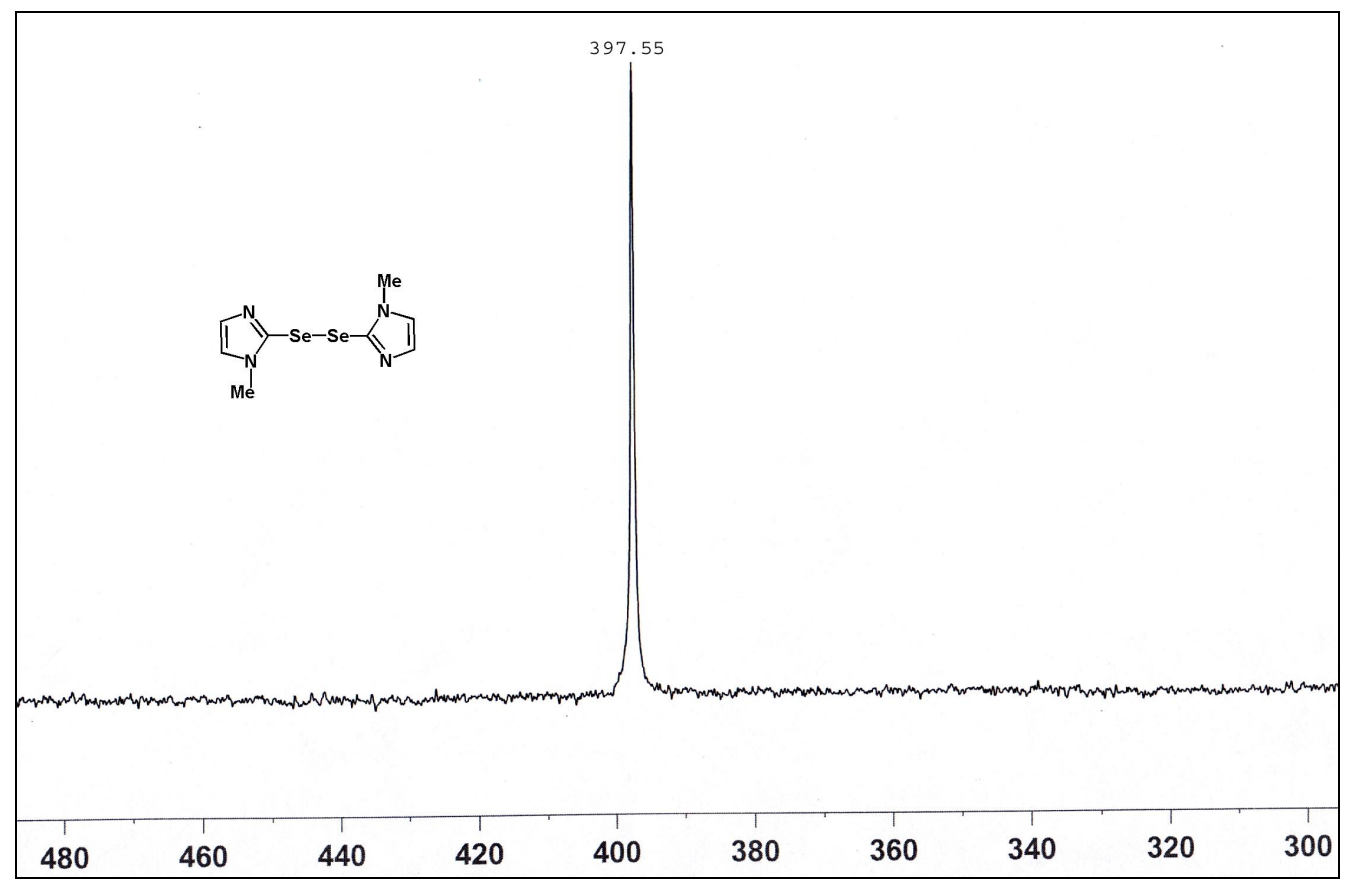

Figure 7. ${ }^{77} \mathrm{Se}$ NMR spectrum of $\mathrm{MSeI}_{\mathrm{ox}}(\mathbf{5})+\mathrm{H}_{2} \mathrm{O}_{2}$ in $\mathrm{D}_{2} \mathrm{O}$. No reaction was observed, which indicates that the cleavage of the $-\mathrm{Se}-\mathrm{Se}-$ bond by the thiol groups of the enzyme is important for the inhibition.

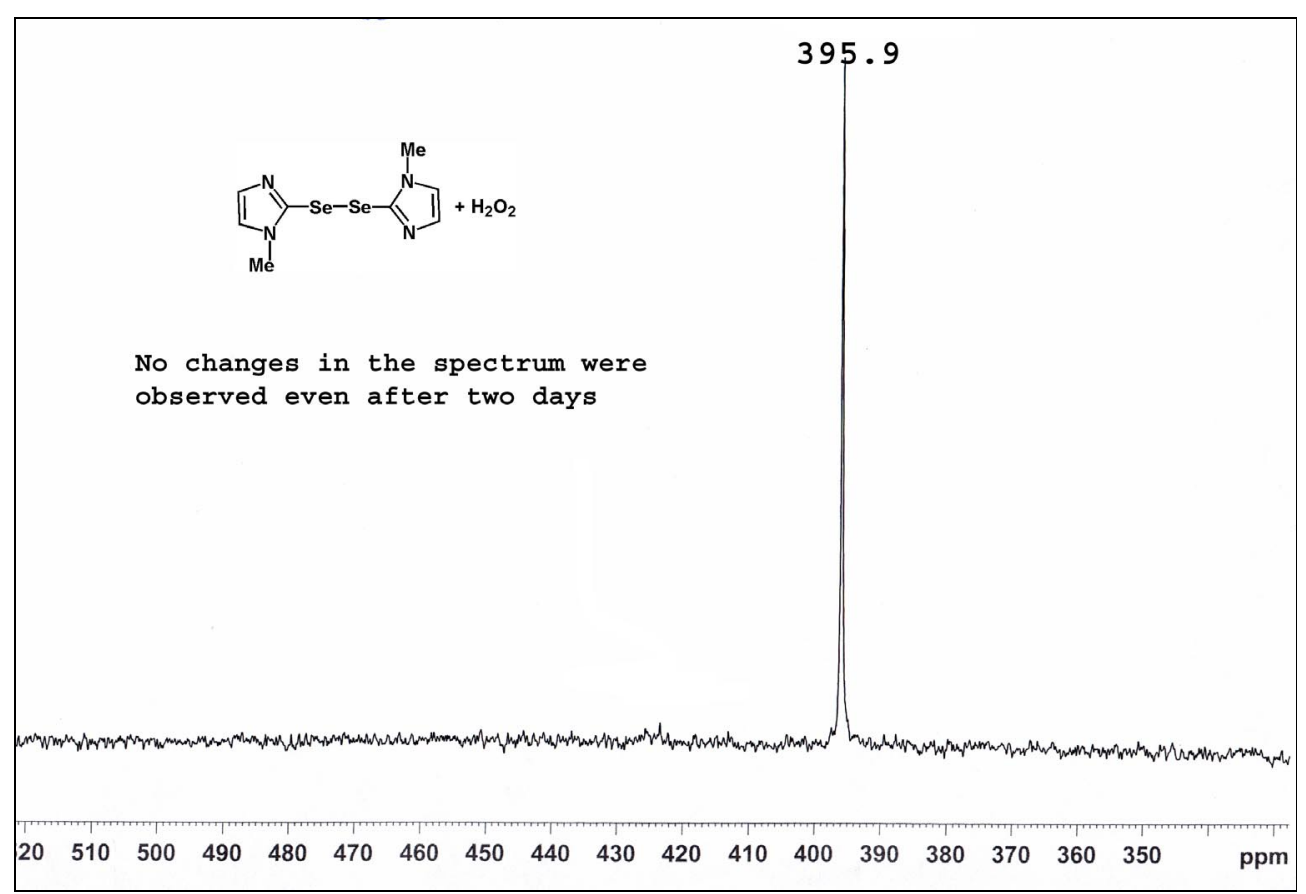


${ }^{77}$ Se NMR studies on the reactivity of selenenyl iodide 8 towards MMI and MSeI.

Figure 8. ${ }^{77}$ Se NMR chemical shift of of diselenide $\mathbf{1 1}$ in $\mathrm{C}_{6} \mathrm{D}_{6}$.

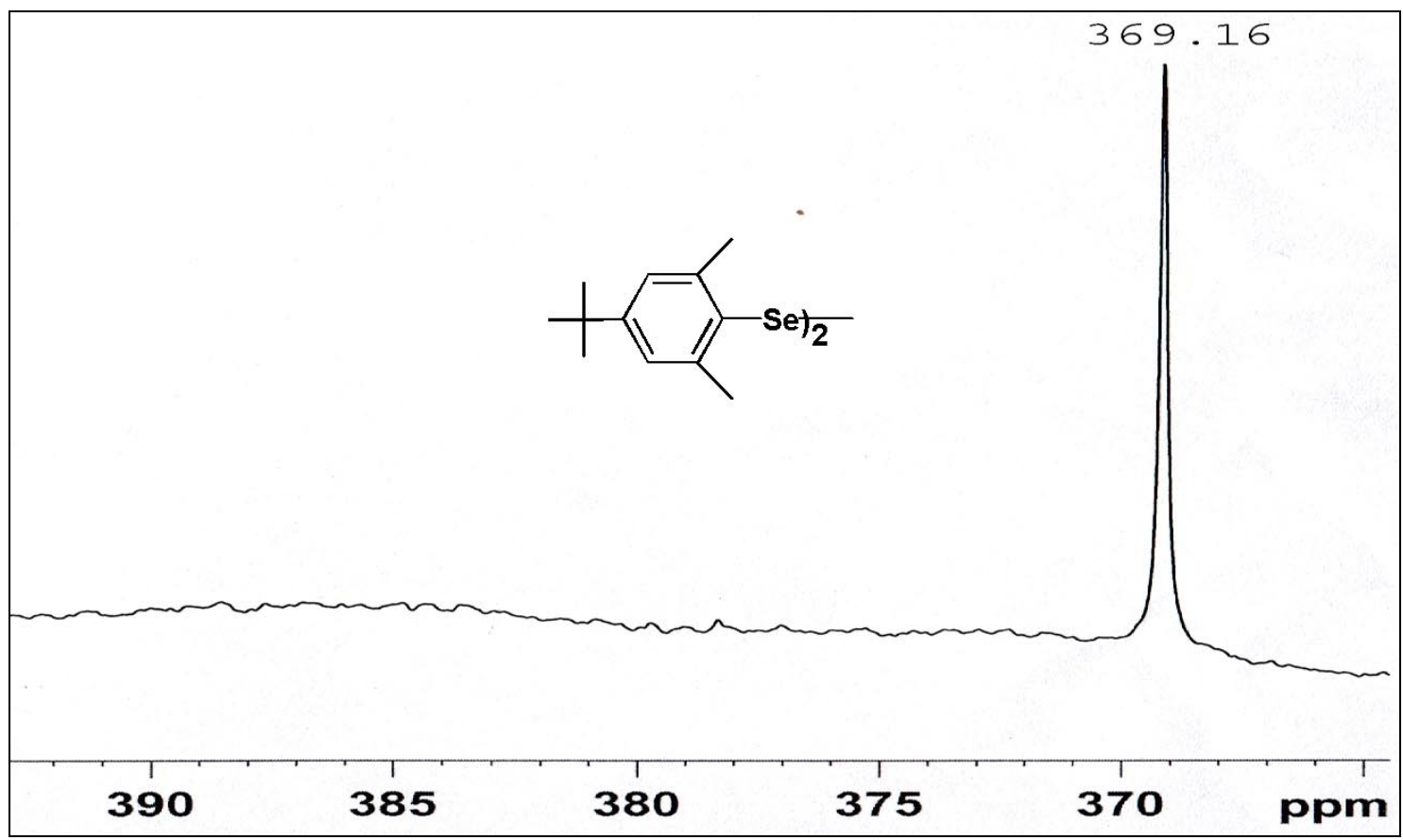

Figure 9. ${ }^{77}$ Se NMR chemical shift of of selenenyl iodide 8 in $\mathrm{C}_{6} \mathrm{D}_{6}$. This compound was prepared from 11 and $\mathrm{I}_{2}$. The signal due to $11369 \mathrm{ppm}$ disappeared completely indication that the selenenyl iodide is not in equilibrium with the diselenide.

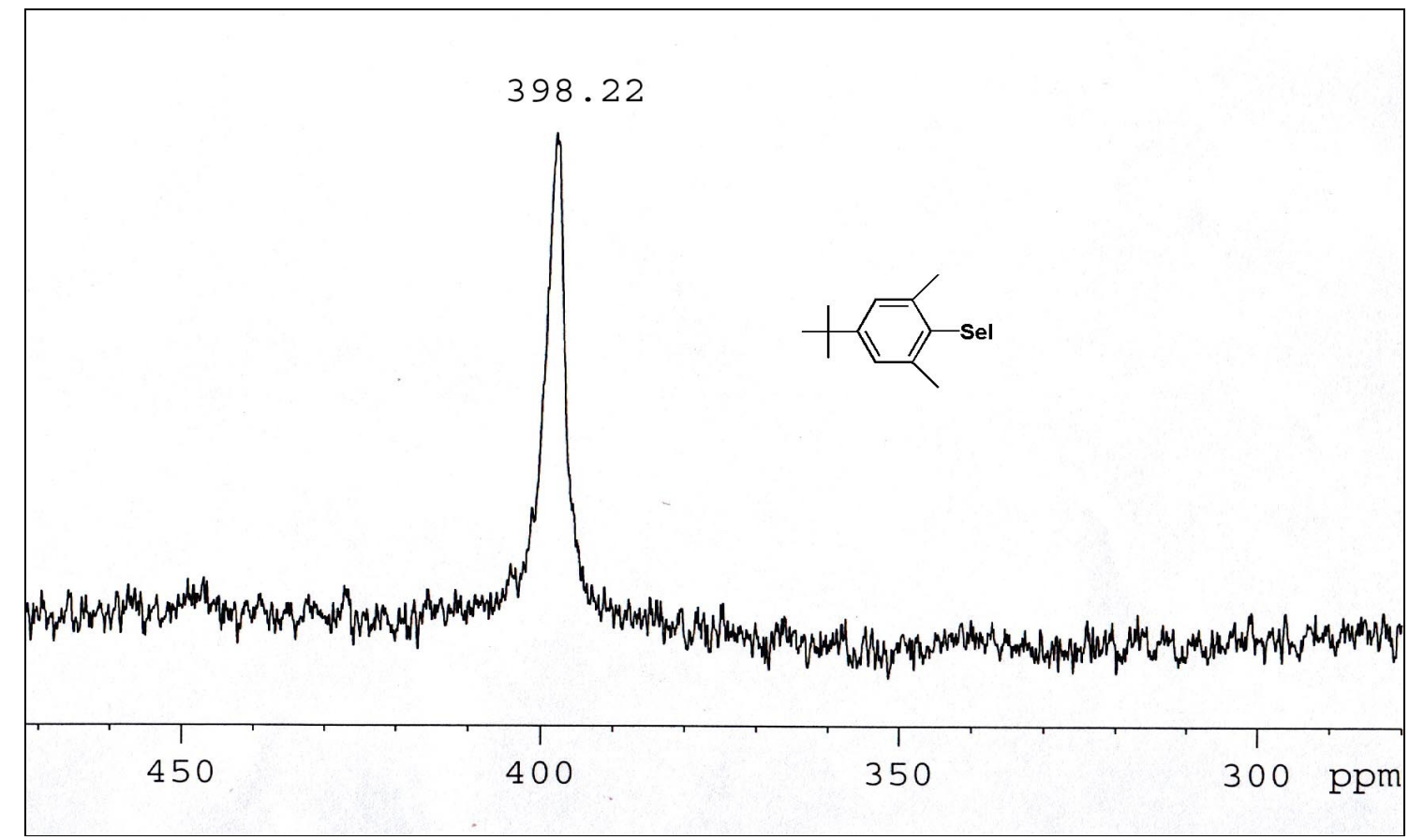


Figure 10. Reaction of selenenyl iodide 8 with $\mathbf{M M I}$ in $\mathrm{CDCl}_{3}$. The expected selenenyl sulfide (9) was observed at $509 \mathrm{ppm}$. A signal at $368 \mathrm{ppm}$, which correspondis to the diselenide 11, is probably due to the disproportination of 9 in solution. The intensity of the signal due to 9 was not reduced further upon keeping the solution longer indicating that compound $\mathbf{9}$ is in equilibrium with 11.

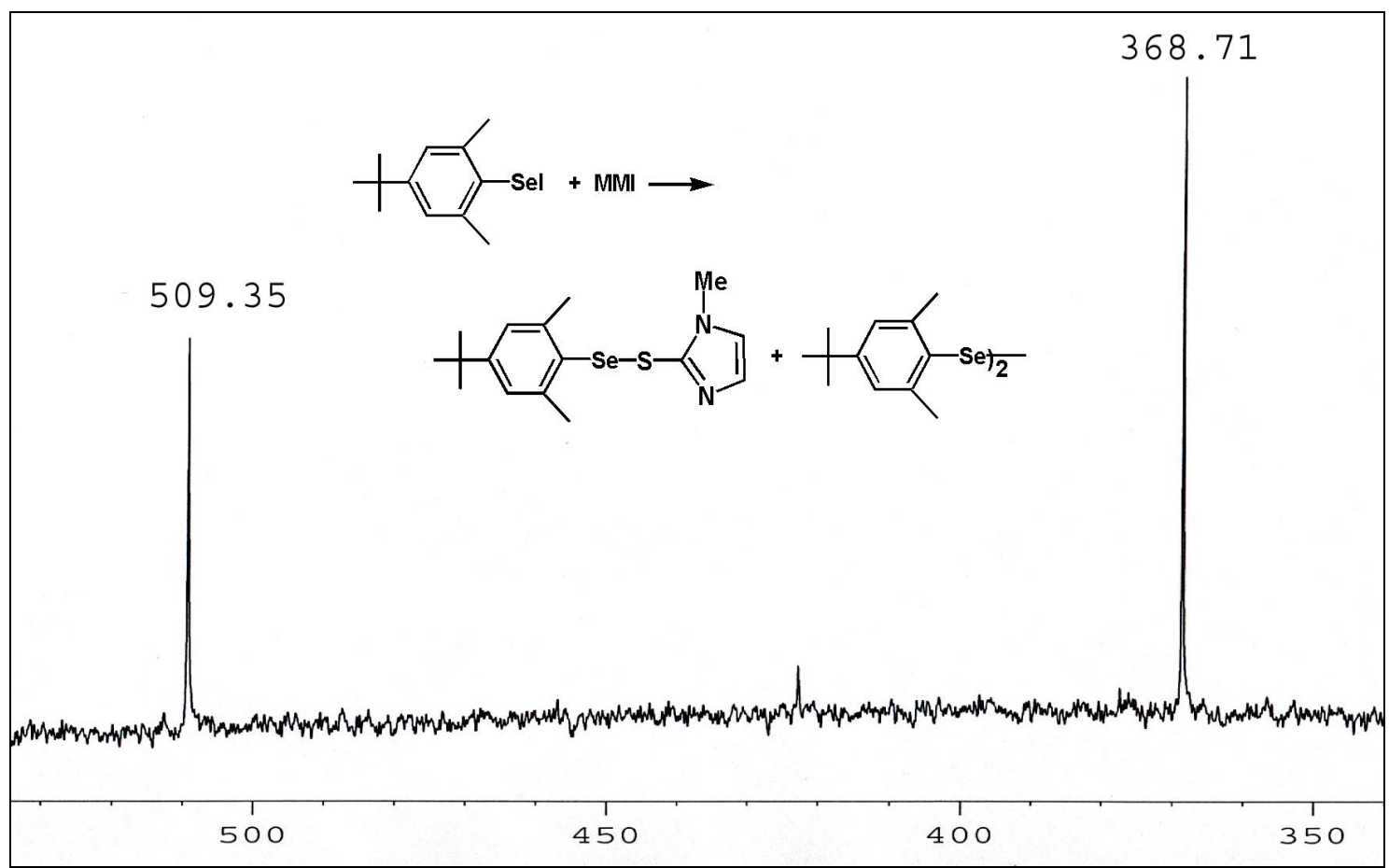

Figure 11. Reduction of selenenyl sulfide 9 by DTT in $\mathrm{CDCl}_{3}$. The signal due to 9 at $509 \mathrm{ppm}$ disappeared completely upon DTT addition. A very intense signal appeared at $368 \mathrm{ppm}$ for the diselenide 11.

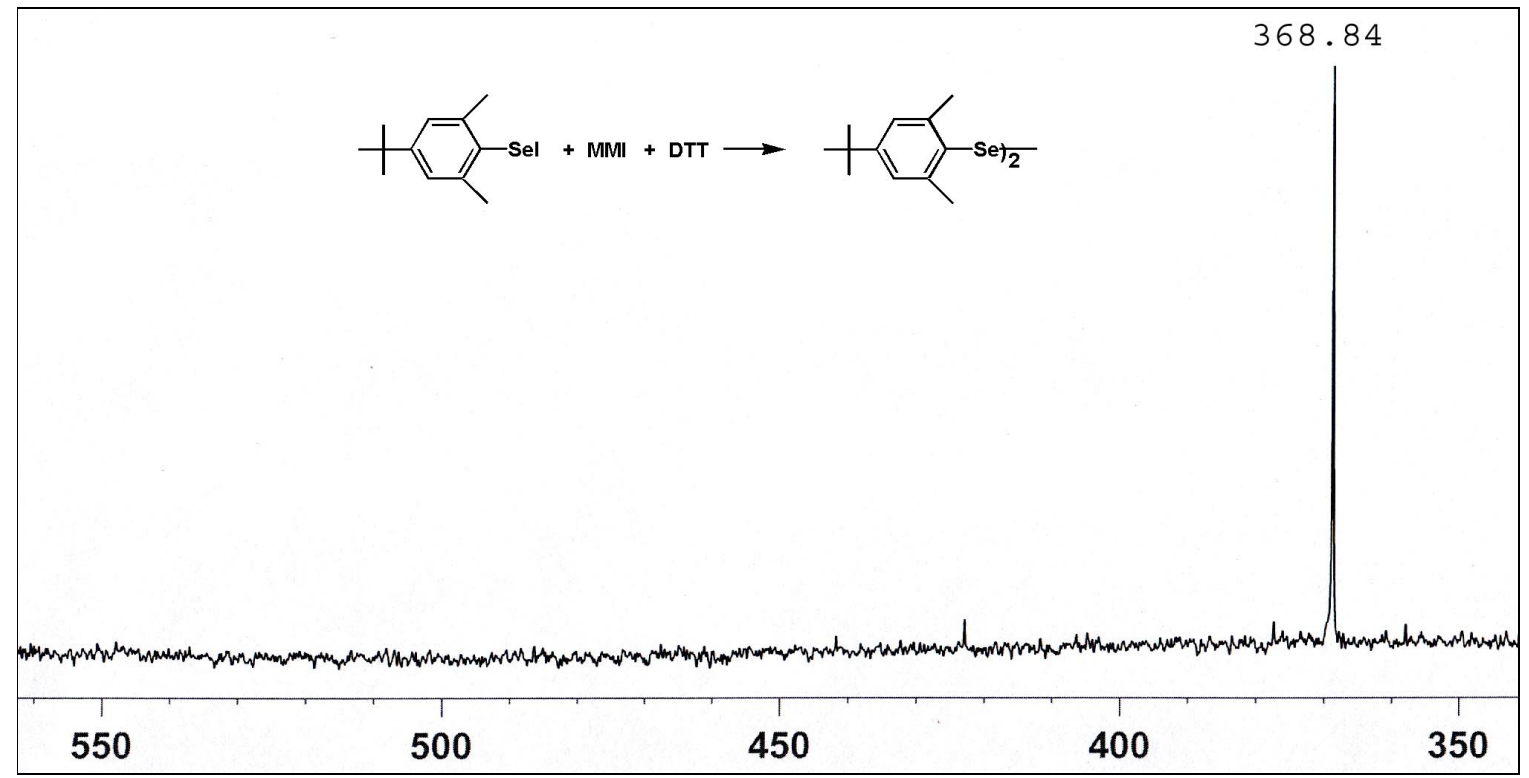


Figure 12. Reaction of selenenyl iodide 8 with $\mathrm{MSeI}$ in $\mathrm{CDCl}_{3}$. Two signals for the expected diselenide (10) were observed at $346 \mathrm{ppm}$ and $420 \mathrm{ppm}$. In addition, a signal at $376 \mathrm{ppm}$ for the diselenide 11, and a signal at $395 \mathbf{p p m}$ for the $\mathbf{M S e I}_{\mathbf{x}}$ are probably due to the disproportination of $\mathbf{1 0}$ in solution.

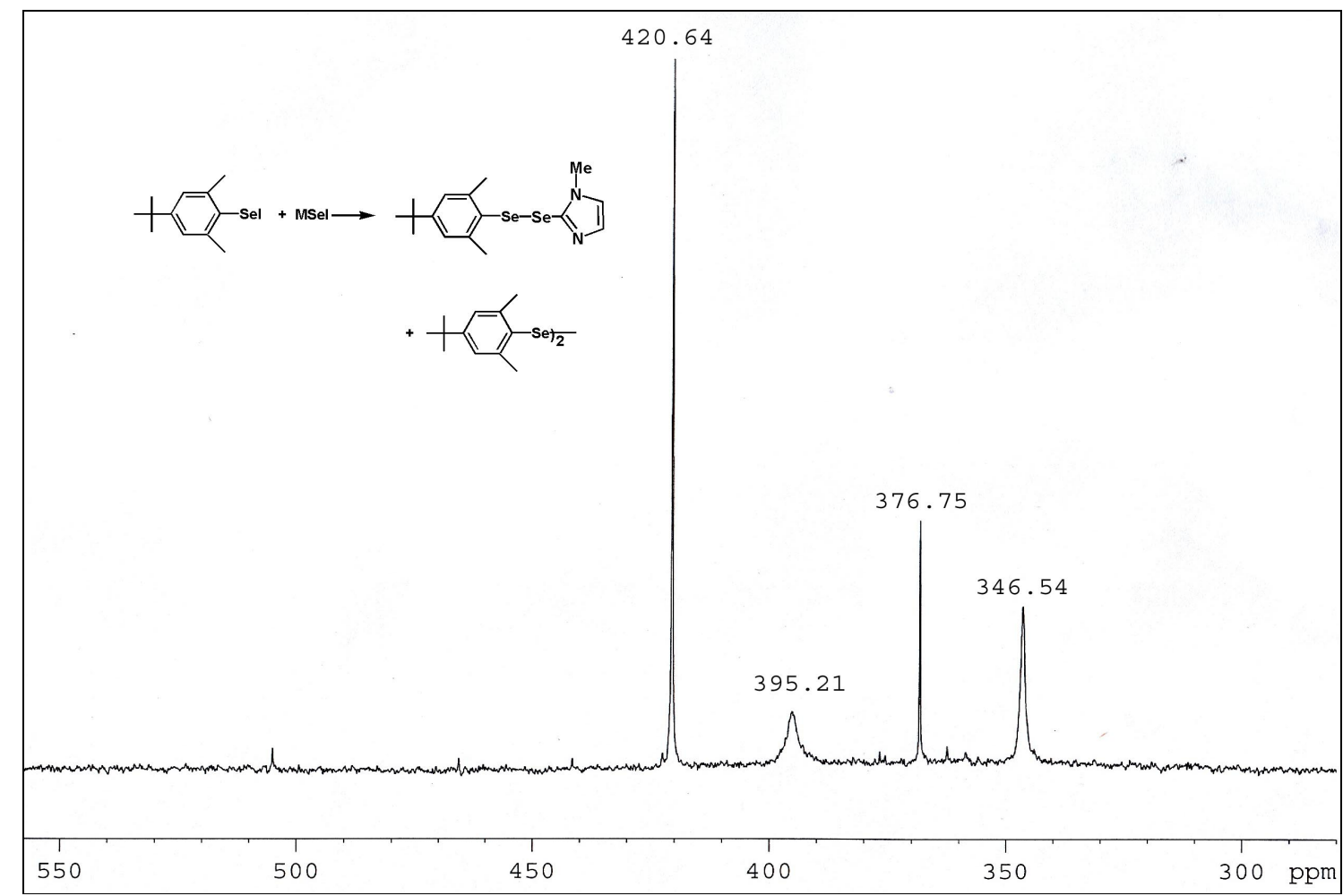

Figure 13. Reduction of diselenide 10 by DTT in $\mathrm{CDCl}_{3}$. The signals at $420 \mathrm{ppm}$ and $346 \mathrm{ppm}$ for $\mathbf{1 0}$ disappeared completely upon DTT addition. A very intense signal appeared at $368 \mathrm{ppm}$ for the diselenide 11.

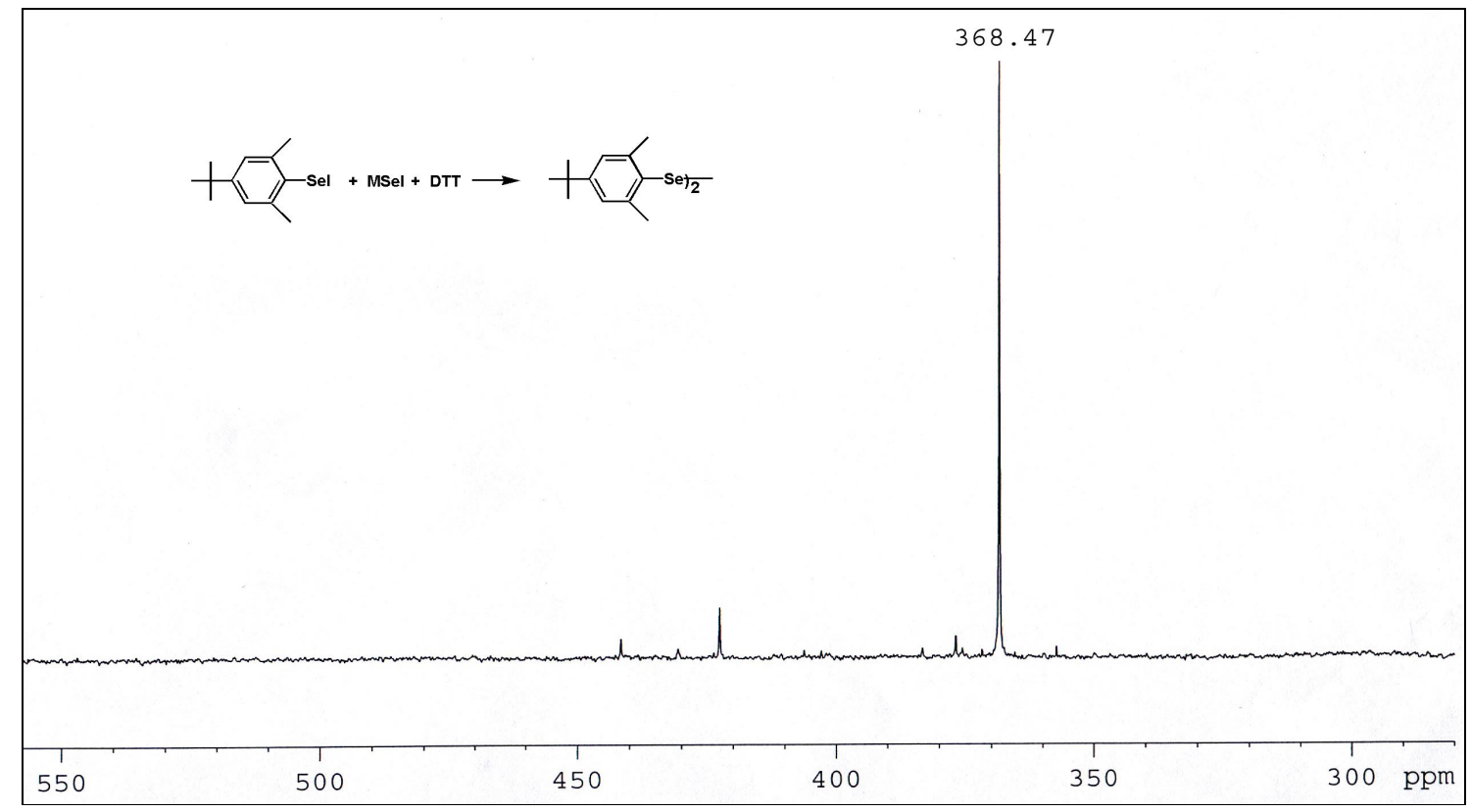


Figure 14. ORTEP view of compound 7 showing non-bonding Se...N interactions.

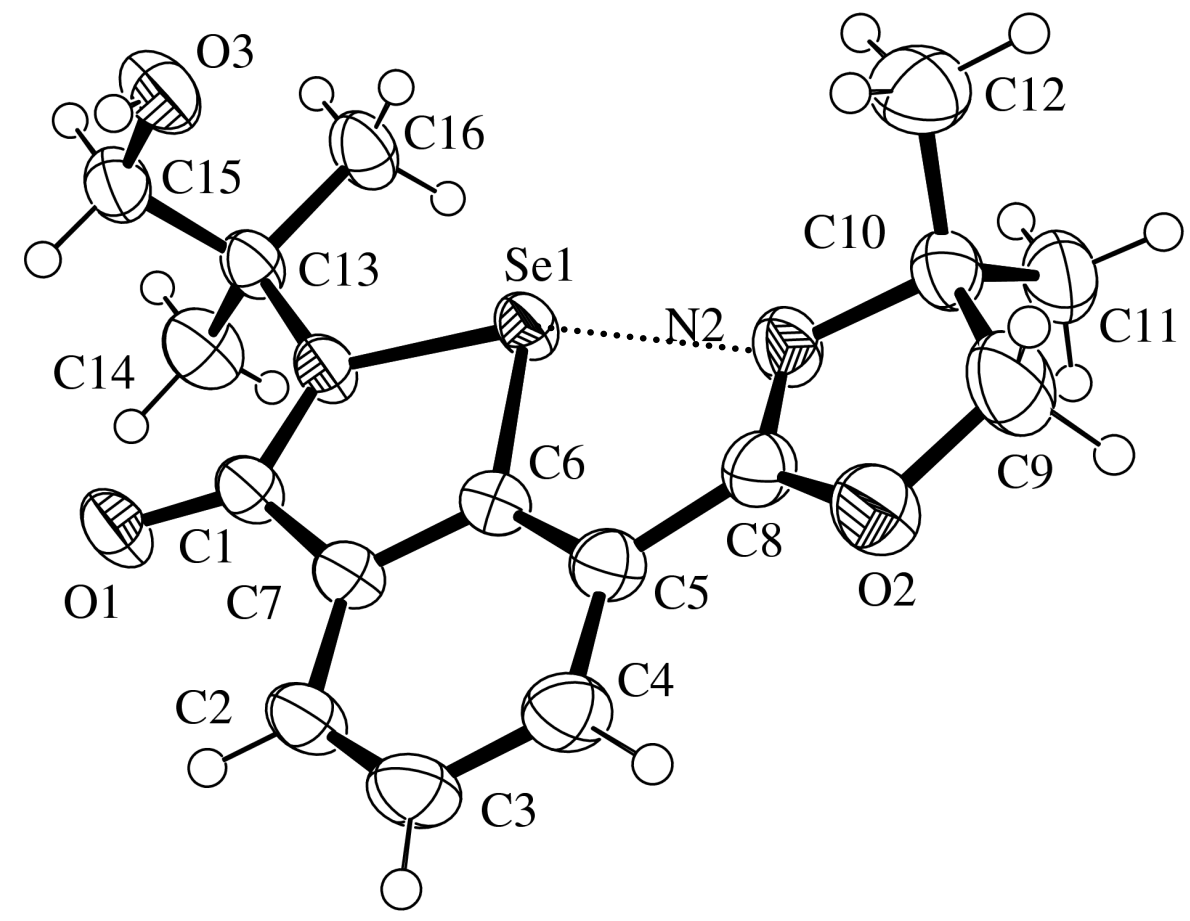

Figure 15. Intermolecular hydrogen bonding in compound 7 .

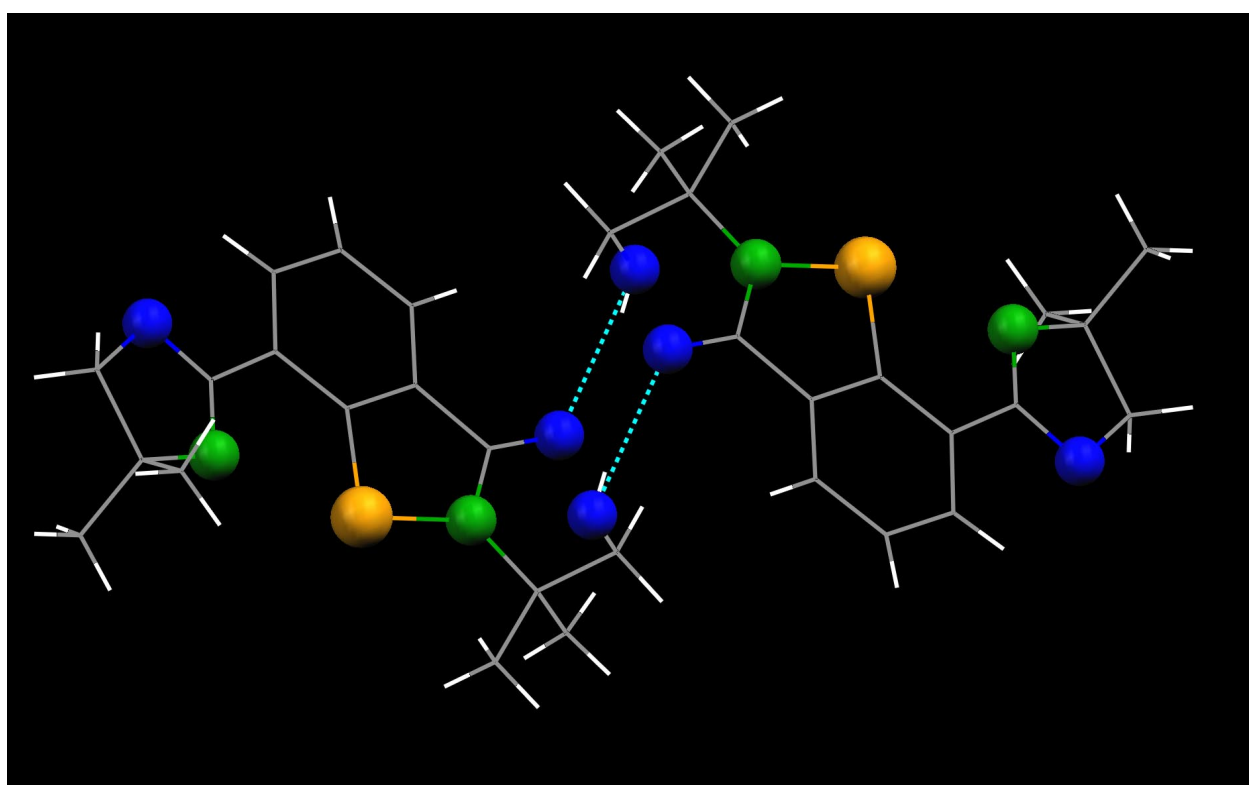

